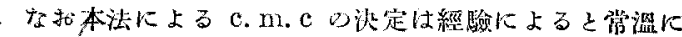

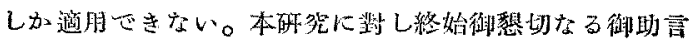

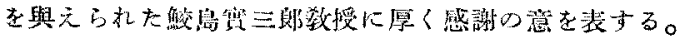

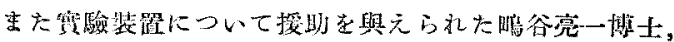
試料を提掑さ机た多くの諸氏に深く謝意を表する。

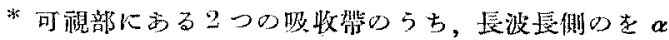

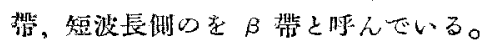

\section{一交 献 -}

1) S. E. Sheppard, A. L. Geddes, J. Cham. Phys., 13, 63 (1945).

2) M.L. Corrin, H. B. Klevens, W.D. Harkins, J. Chem. Phys., 14, 216 (1946).
3) 寺山 䛋, 化學の領域. 1, 185 (1947).

4) L. A. Du Bridge, Phys. Rev., 37, 392 (1931).

5) H. B. Harkins, J. Phys. \& Colloid Chem., 52, 130 (1948).

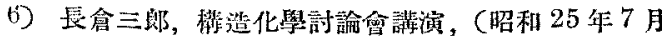
本点).

7) L. Michaelis, J. Phys. \& Colloid Chem., 54, 1 (1950).

8) R. O. Merril et al., J. Am. Chem. Soc., 70, 2460, $3683(1948)$.

9) L. Michaelis, 8; 䓋照。

\title{
金一，白金一及び硫化䂤素ソ゚ルの凍結に關する研究（第1 報）
}

\section{凍 結 影 響 の 諸 觀 察}

宇野昌平・伊知地直治

I. 緒言

ゾルの谏結に關する研究は可成り古くからあるがりこ れらは多く定性的义は䰜片的である。それらを通翼する

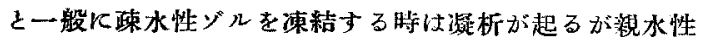
ゾルK於ては必ずしる一攼しないるのの如くである。箸 者の一人宇野はゲルの涷結についての研究を行つていた がゾルの凍結との關連につき检討の必要を感じたので種 んのゾルの凍結に關与る研究走企國した。本報告はその最 切のるので疎水性ジルの代表的なるのとして金一，白金-

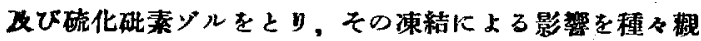
察した戱圭まとめたるのである。

\section{II. 金ゾルの調集法と東結の影饗}

金ゾルを $0^{\circ} \mathrm{C}$ 以下に溶却して堔結さ吼，主溫に放置

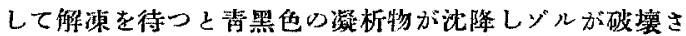
れていることがわかる。金ゾルについては多くの人の様 タな砸觉がありその調製法にも種々な考案がある。それ らは望元劑或は安定劑の相違であると見做し得るがそれ

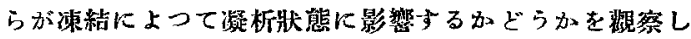
た。解凍液は何九を透心分離することによつて凝析物が 容易に沈降するのでその上澄液の色調亚びに分析に上つ て金ゾルの殘存量を明かにすることが出來た。その結果 を第1表にまとめた，表に見石如く（1），(2) 及び（5)

第 1 表 各種調製法による金ゾルの $-10 \% \mathrm{C}$ 凍䊅

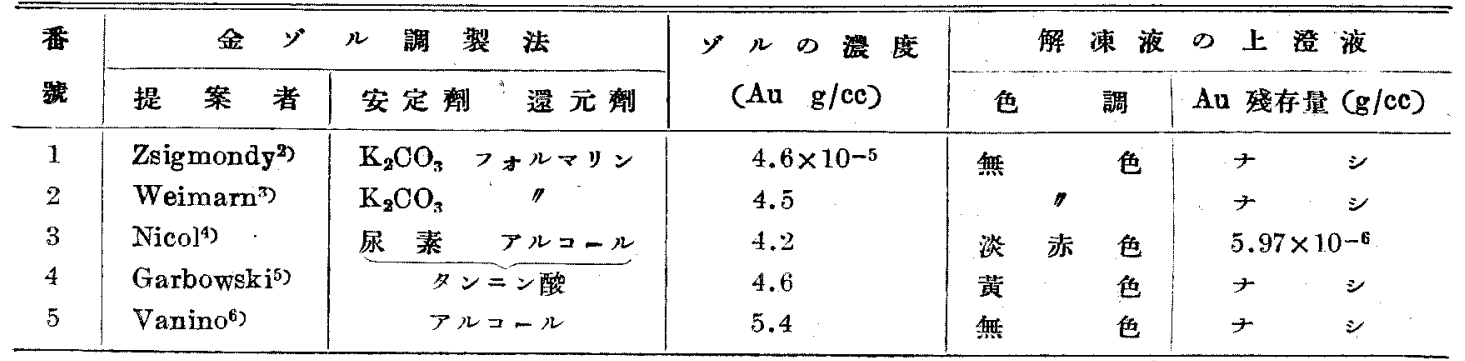


は何れも完全に㠜析し，又(4)は上澄液が黄色だある がこれはタンニン酸の酸化生成物の巴と考えら机液中の

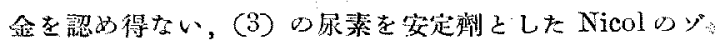

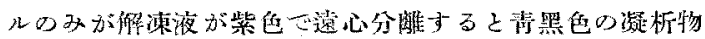
方汇隆し，淡赤色の金ゾルを残した。その上澄液中心全

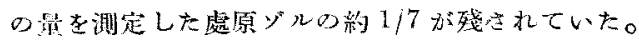

何故にこの Nicolのゾルだけが完全な凝析をしないの

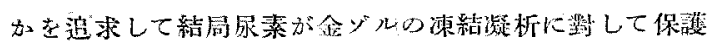
作用老持つているものてあることを明かにした。毁ち尿

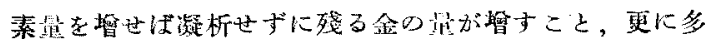
く加えれば完全に凝析を妨げて梠㪗の影然が全くないこ

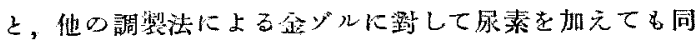

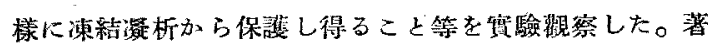
者等は尿素の如き金ゾルの電解質凝析に瑟して保護能力 のないものが凍結㠜析に對しては明かな保護作用を是す

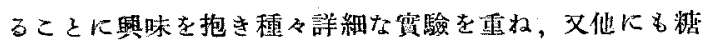
類が同樣な保護能力を示すことを見出した。

\section{III. 凍結溫度の影響}

金，白金一改び硫化砣素ゾルをそれぞれ3 本ずつの試

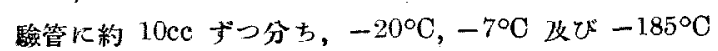

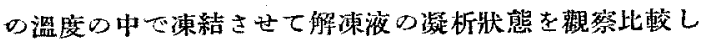
た。金ゾルは Weimarn ${ }^{3}$ の方法により, 白金ゾルは Lottermoser ${ }^{\S}$, 硫化砋素ゾルは Schulze ${ }^{9}$ の方法により

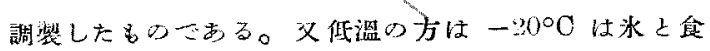

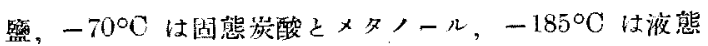
酸素によつて㭩た。

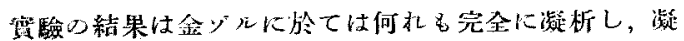

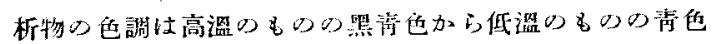
に變化し，又その粒子が低溫のもの程細かいことが肉眼

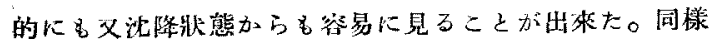

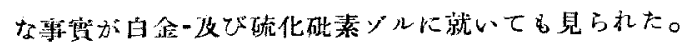

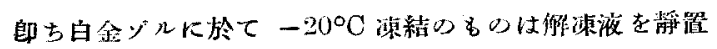
すると完全に無色透明な液を得るが， $-70^{\circ} \mathrm{C}$ 及び -185

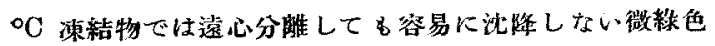

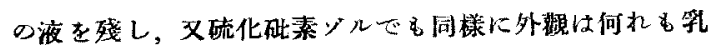

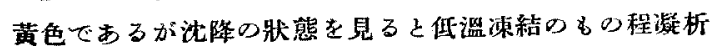
粒子が細かいてとが定性的ながら数祭された。

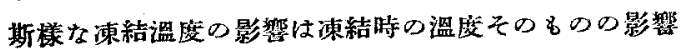

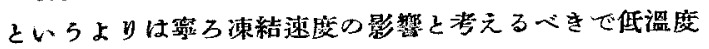
の場合程米の結晶が發生並びに成長する速度が大である 第に起る現象と見られる。郎ち湅結によるどルの疑析が 如何なる原因又は機構によつて起るかは晢らく措き，低

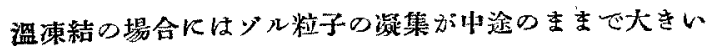

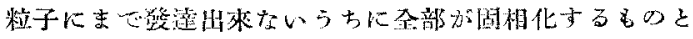
悲像し得了。

\section{IV. 凍結による凝析開始の時期}

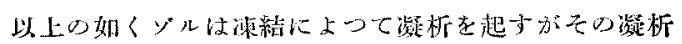

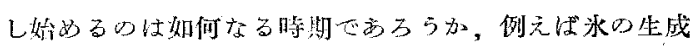

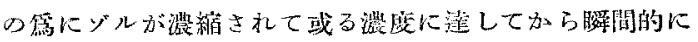

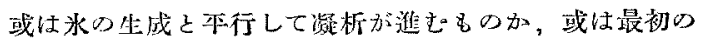

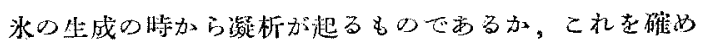
る篇に金デル就て二，三の筧踰在行い，結同策三の場

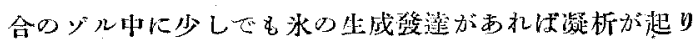
凍絈の進行に本行して㠜析が進むものであるてと琶め

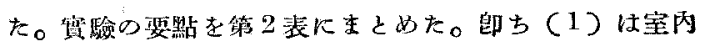
放置して標蕉にしたるの（2）は $0^{\circ} \mathrm{C}$ 保存で影怔がな

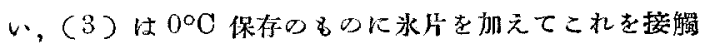

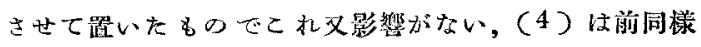

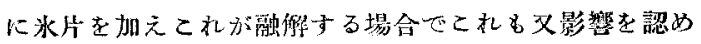

第 2 表 金ゾルの凝析開始の時期に閶する嘼驗

\begin{tabular}{|c|c|c|c|c|c|c|c|}
\hline 路 & 處 & 理 & 過 & 程 & $\begin{array}{l}\text { 保持 } \\
\text { 時間 }\end{array}$ & 液留變化 & 影 \\
\hline 1 & 窒 & 溫 & 放 & 置 & 40分 & $10 \mathrm{cc}$ & - \\
\hline 2 & $0^{\circ} \mathrm{O}$ & & 保 & 存 & " & $"$ & $ナ \quad シ$ \\
\hline 3 & $=0^{\circ} \mathrm{C}$ & 保存 & 水㸝 & 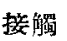 & $"$ & $10 \rightarrow 10.7 \mathrm{cc}$ & \multirow{3}{*}{$\begin{array}{l}+\quad \equiv \\
+\quad 三 \\
\text { 紫尔色, } \\
\text { 㠜 析 }\end{array}$} \\
\hline 4 & $+2^{\circ}-$ & $-+3^{\circ} \mathrm{C}$ & ，承 & 融解 & 13 & $10 \rightarrow 152 . \mathrm{cc}$ & \\
\hline 5 & -200 & $-3^{\circ}$ & , 头 & 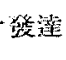 & 10 & $10 \rightarrow 9.0 \check{c c c}$ & \\
\hline
\end{tabular}

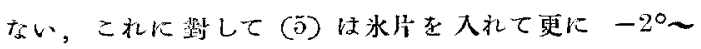

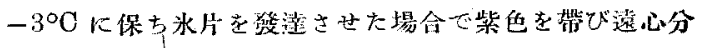

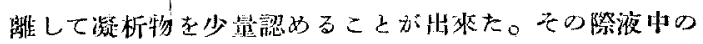
水が氷になつた部分は保少で浱縮が行われた篇とは言い

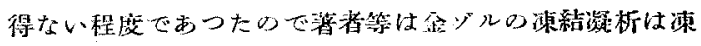

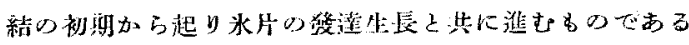
上将元た。

\section{V. デルの pH と凍結の影響}

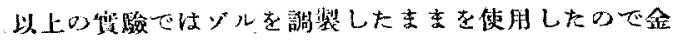
ゾルは pH 6.6, 白金ゾルは 6.4, 硫化砳素ゾルは 5.2 位のものであつた。元本これらのン゙ルは酸性側で不安定 一微アルカり性で若干安定性を崰子ことが知られてい

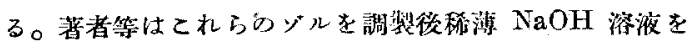

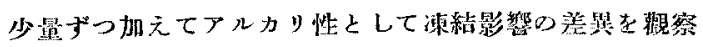
した。金ゾルに於ては $\mathrm{pH} 13$ 位にしてる涷結によつて 完全に凝析するがそ心㠜析物粒子は著しく微絧をなり， 白金一改び硫化吪素ゾルではアルカリ性にする程凍結潞 


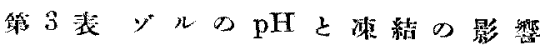

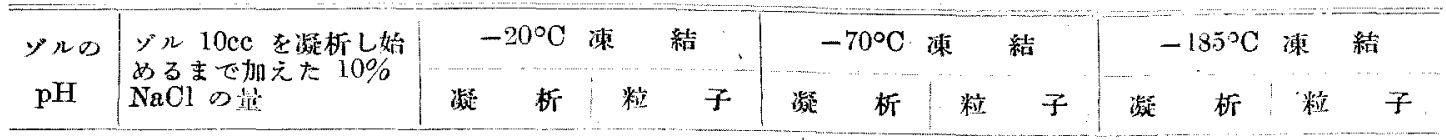

(1) 金ゾル (Weimarn)

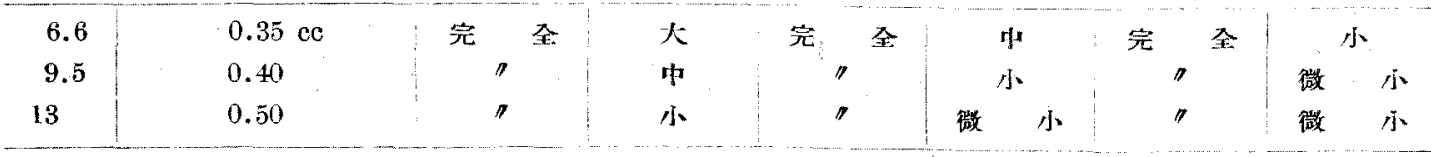

(2) 白金ゾル (Lottermoser)

\begin{tabular}{|c|c|c|c|c|c|c|c|}
\hline 7 & $0.65 \mathrm{cc}$ & 完 全 & 大 & 完 全 & 小 & 完 全 & 小 \\
\hline 10 & 0.75 & 約 $90 \%$ & - & 約 $60 \%$ & $\longrightarrow$ & 約 $50 \%$ & - \\
\hline 13 & 0.95 & 約 $80 \%$ & $\longrightarrow$ & 的 $20 \%$ & - & 約 $10 \%$ & $\longrightarrow$ \\
\hline
\end{tabular}

(3) 硫化䂤素ゾル (Scbulze)

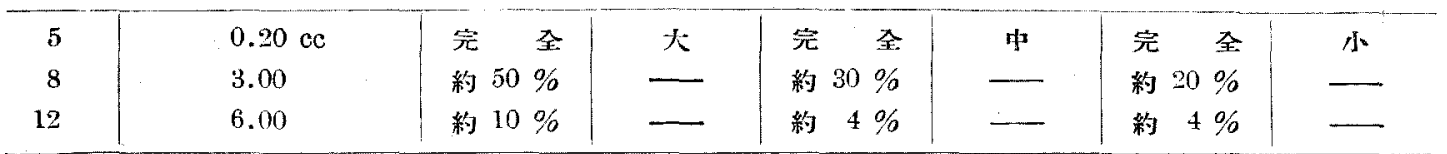

析が不完全で，殊に $-185^{\circ} \mathrm{O}$ 凍結の場合には小部分が 凝析するに過ざい。白全一改び硫化砒素ジルを比較す ると硫化砒素の方がアルカリ性側に一屡安定で湅結に上

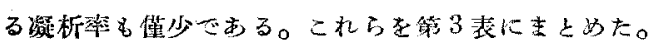

\section{VI. 總 括}

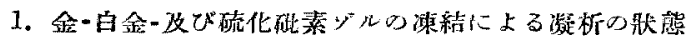
を觀察した。

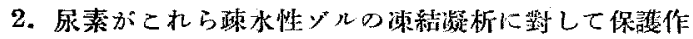
用を是するこ己を見㟧した。

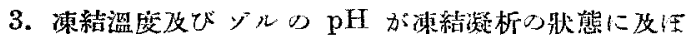
す影理蕰蔡した。

4.ゾルの凍結に上る凝析は湅絬閶绐の䘞斯から始まる ものてあることを認めた。

\section{一文献 -}

1) Bobertag, Feist, Fischer, Ber, 41, 3675 (1908) 其他。
2) R. Zsigmondy, Z. analyt. Chem., 40,697(1901); 鮫点，膠翼學211 頁 (昭 22).

3) P. P. Weimarn, 大阪工試報, 9, (7), (1928)。 鮫泉, 膠質學 213 頁 (昭 22).

4) H. Nicol, I. Soc. Chem. Ind. 47, $343 \mathrm{~T}$ (1928).

5) L. Garbowski, Ber,, 336, 1215 (1903); Hauser, Lynn, Experiments in Colloia Chemistry, (1940) p. 17 .

6) L. Vanino, Ber., 38, 463 (1905); Hauser and. Lynn, Experiments in Colloid Chemistry, p. 19 (1940).

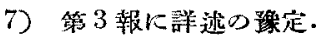

8) Lottermoser "Anorganische Kolloids, s, 33 $(1901)$.

9) Schulze, J. prakt. Chem., (2), 95, 431 (1882); 鮫泉，想啠學 219 頁 (昭 22).
昭和 26 年 6 月5 日印刷 登行急編集人 印蒯人 印刷 所
昭和 26 年 6 月 10 日行

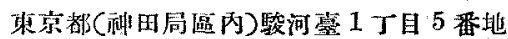
来宗都北區上中里町 153 東京都北區上中里町 153
[定偩 100 圆(添料 7 圓)]

岩域 廣吉 倉澤㨁男 合名會 社双交脚

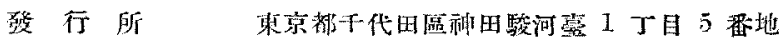

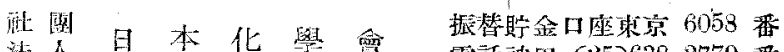

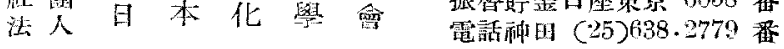

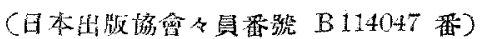

